\title{
PEMENUHAN HAK TAHANAN DALAM PELAYANAN PENDIDIKAN DAN PENGAJARAN MELALUI PROGRAM PEMBERANTASAN BUTA AKSARA DI RUTAN KELAS IIB PEMALANG
}

\section{Tenisia Agustin}

Program Studi Bimbingan Kemasyarakatan, Politeknik Ilmu Pemasyarakatan

Email: tenisiaagustin25@gmail.com

\section{Abstract}

This paper discusses the issue of the fulfillment of the Rights and Obligations of Prisoners in the context of realizing the goal of the 3rd Indonesian nation in the fourth paragraph of the opening of the 1945 Constitution, namely "Educating the life of the nation" carried out by the government, especially in the Class IIB Pemalang detention center. The purpose of this study is to prepare the Correctional Assistance Citizens to be a smart nation in accordance with the objectives of the Indonesian nation as contained in the fourth paragraph of the 1945 Constitution. The data collection technique in this study uses primary data with informants, namely prisoners in the Class IIB Pemalang detention center. The method used is the qualitative method with case studies and this type of legal research is empirical. Based on the results of the research, it is necessary to carry out a training activity that is able to overcome the inability to read and write experienced by both prisoners and prisoners, it is hoped that it can facilitate the communication process and realize the goal of the $3 r$ Indonesian nation in the fourth paragraph of the 1945 Constitution.

Keyword: jail; prisoner's rights; prisoner service; prisoner care; education

\begin{abstract}
Abstrak
Tulisan ini membahas tentang isu terpenuhinya hak dan Kewajiban Tahanan dalam rangka mewujudkan tujuan bangsa Indonesia ke-3 pada alinea ke-IV Pembukaan UUD 1945 yaitu "Mencerdaskan kehidupan bangsa" yang dilakukan pemerintah khususnya di lingkungan Rutan Kelas IIB Pemalang. Tujuan dari penelitian ini adalah mempersiapkan Warga Binaan Pemasyarakatan menjadi bangsa yang cerdas sesuai dengan tujuan bangsa Indonesia yang terdapat pada alinea ke-IV UUD 1945. Teknik pengumpulan data pada penelitian ini menggunakan data primer dengan sumber informan yaitu tahanan di Rutan Kelas IIB Pemalang. Metode yang digunakan yaitu metode Kualitatif dengan studi kasus dan jenis penelitian hukum ini bersifat empiris. Berdasarkan hasil penelitian perlu dilaksanakan suatu kegiatan pelatihan yang mampu mengatasi ketidakmampuan dalam membaca dan menulis yang dialami oleh tahanan maupun narapidana diharapkan dapat mempermudah proses komunikasi, dan mewujudkan tujuan bangsa Indonesia ke-3 pada alinea keIV UUD 1945.
\end{abstract}


Kata kunci: rumah tahanan; hak tahanan; pelayanan tahanan; perawatan tahanan; pendidikan

\section{Pendahuluan}

Indonesia mengakui bahwa negara ini adalah negara hukum yang tertuang di Undang-Undang Dasar 1945 yaitu pasal 1 ayat 3 yang berbunyi "Negara Indonesia adalah negara hukum", jika ada seseorang melakukan tindakan melanggar aturan, maka ia berhak untuk mendapatkan suatu hukuman karena dianggap melanggar hukum. Sistem penjaraan dalam sejarahnya dikenal sebagai reaksi masyarakat sebagai adanya tindak pidana yang dilakukan oleh seorang pelanggar hukum. Oleh karena itu pidana penjara juga disebut sebagai pidana hilangnya kemerdekaan. Dalam hal ini sistem pemenjaraan sangat menekankan pada unsur balas dendam dan penjeraan, terpidana diperlakukan sebagai objek semata yang dirampas kemerdekaannya, tenaga mereka seringkali dipergunakan untuk kegiatan-kegiatan fisik. Ini menjadikan sistem penjaraan jauh dari nilai-nilai kemanusiaan dan hak asasi manusia. Bagi negara Indonesia yang berdasarkan Pancasila, pemikiran-pemikiran baru mengenai fungsi pemidanaan yang tidak lagi sekadar penjeraan tetapi juga merupakan suatu usaha rehabilitasi dan reintegrasi sosial Warga Binaan Pemasyarakatan.

Berdasarkan pemikiran tersebut, maka sejak tahun 1964 sistem pembinaan bagi narapidana dan anak pidana telah berubah secara mendasar, yaitu dari sistem kepenjaraan menjadi sistem pemasyarakatan. Sistem Pemasyarakatan adalah suatu tatanan mengenai arah dan batas serta cara pembinaan Warga Binaan Pemasyarakatan berdasarkan Pancasila yang dilaksanakan secara terpadu antara pembina, yang dibina, dan masyarakat untuk meningkatkan kualitas warga binaan pemasyarakatan agar menyadari kesalahan, memperbaiki diri, dan tidak mengulangi tindak pidana sehingga dapat diterima kembali oleh lingkungan masyarakat, dapat aktif berperan dalam pembangunan, dan dapat hidup secara wajar sebagai warga yang baik dan bertanggung jawab (Wulandari, 2015).

Berdasarkan Surat Keputusan Menteri Kehakiman RI, tanggal 20 September 1981 Nomor : M.04- PR.07.03 Tahun 1985 tentang Organisasi dan Tata Usaha Rumah Tahanan Negara, bahwa rutan adalah unit pelaksana teknis dalam bidang penahanan yang gunanya untuk kepentingan dari penyidikan, penuntutan dan pemeriksaan di sidang pengadilan, yang posisinya berada di langsung kepada Kepala Kantor Wilayah Kementerian Hukum dan HAM RI (Christian, 2020). Tahanan adalah tersangka atau terdakwa yang ditempatkan dalam RUTAN/Cabang RUTAN. Di dalam Rumah Tahanan sendiri terdapat perawatan yang di berikan untuk tahanan dan merupakan proses pelayanan tahanan yang dilaksanakan mulai dari penerimaan sampai dengan pengeluaran tahanan dari Rumah Tahanan Negara (RUTAN).

Menurut Undang-Undang Nomor 20 Tahun 2003 tentang Sistem Pendidikan Nasional Pasal 1 poin 1 yang berbunyi : "Pendidikan adalah usaha sadar dan terencana untuk mewujudkan suasana belajar dan proses pembelajaran agar peserta didik secara aktif mengembangkan potensi dirinya untuk memiliki kekuatan spiritual keagamaan, 
pengendalian diri, kepribadian, kecerdasan, akhlak mulia, serta keterampilan yang diperlukan dirinya, masyarakat, bangsa dan negara" (Raharjo, 2014). Tujuan dari pemberian pembinaan berupa pendidikan tersebut diharapkan dapat memasyarakatkan terpidana sehingga menjadikannya orang yang baik dan berguna, menyelesaikan konflik yang ditimbulkan tindak pidana, memulihkan keseimbangan dan mendatangkan rasa damai dalam masyarakat serta membebaskan dari rasa bersalah (Ermis Suryana, 2017).

Munculnya Pemasyarakatan sebagai filosofi penghukuman ini secara formal telah memperlihatkan komitmen Indonesia pada tatanan konseptual dalam menyelenggarakan pemidanaan yang manusiawi serta melindungi Hak Asasi Manusia. Tentu saja ini menjadi peluang besar bagi realisasi hak-hak narapidana sesuai dengan standar yang telah ada, maupun peluang bagi pembaruan sistem dan instrumentasi, seperti formalisasi pedoman perlakuan dan pemenuhan hak-hak spesifik yang belum diatur sebelumnya (Sulhin, 2010). Keberadaan sebagian kecil masyarakat Indonesia yang masih belum bisa membaca dan menulis menandakan masih belum tercapainya tujuan bangsa Indonesia dalam mencerdaskan bangsa. Salah satunya Warga Binaan Pemasyarakatan yang berada di Rumah Tahanan Negara Kelas IIB Pemalang. Penyebabnya antara lain faktor tingginya kemiskinan, desakan ekonomi yang menuntut bekerja keras, malas belajar secara formal karena sebagian besar materinya bersifat teori atau tidak dapat secara langsung dirasakan manfaatnya, hingga rasa malu mengakui kekurangan dirinya dan rendahnya pendidikan yang di dapat.

Hal tersebut saya temukan setelah melakukan pengamatan di Rumah Tahanan Negara Kelas IIB Pemalang dari jumlah 174 Warga Binaan Pemasyarakatan yang bertempat di dalam Rutan Kelas IIB Pemalang terdapat 14 tahanan/narapidana yang tidak bisa membaca dan menulis dengan data sebagai berikut :

Tabel. 1 Kapasitas Ruang Rutan Kelas IIB

\begin{tabular}{ccc}
\hline KAMAR & TAHANAN & NARAPIDANA \\
\hline Blok A & 1 Orang & 6 Orang \\
\hline Blok B & - & 7 Orang \\
\hline Blok C & - & - \\
\hline JUMLAH & 1 Orang & 13 Orang \\
\hline TOTAL & & $\mathbf{1 4}$ Orang \\
\hline
\end{tabular}

Sumber: Kesatuan Pengamanan Rutan Kelas IIB Pemalang

Perlunya optimalisasi pemberian Pelayanan kepada tahanan maupun narapidana di Rutan Kelas IIB Pemalang, salah satu contoh permasalahan yang saya temukan saat melakukan pengamatan dari ketidakmampuan beberapa tahanan maupun narapidana yang tidak bisa membaca dan menulis yaitu saat WBP akan menggunakan fitur layanan berupa Self Service karena tidak memiliki kemampuan membaca. kemudian 
permasalahan yang ditemukan saat melakukan pengamatan dari ketidakmampuan beberapa tahanan maupun narapidana yang tidak bisa membaca dan menulis yaitu terdapat kesulitan penggunaan layanan video call dan wartel untuk dapat berkomunikasi kepada keluarga di rumah akibat dari tidak adanya kemampuan untuk membaca dan menulis nomer keluarga yang ingin dihubungi sehingga harus dibantu oleh petugas yang mengawasi, selanjutnya ketidakmampuan warga binaan pemasyarakatan dalam membaca berakibat pada tidak memahaminya tata tertib yang berlaku di dalam Rutan maupun Peraturan yang terpasang di sekitar blok hunian, sehingga menyebabkan kurang adanya kesadaran dengan peraturan yang berlaku di dalam Rutan Kelas IIB Pemalang.

Sesuai dengan Surat Keputusan Menteri Kehakiman R.I. No. M. 04. PR. 07. 03. Tahun 1985 tentang Organisasi dan Tata Kerja Rumah Tahanan Negara (Rutan), Tugas Rumah Tahanan Negara (Rutan) adalah Melaksanakan perawatan terhadap tersangka atau terdakwa sesuai dengan peraturan perundang-undangan yang berlaku. Fungsi Rumah Tahanan Negara (Rutan) adalah :

1. Melakukan Pelayanan Tahanan;

2. Pemeliharaan Keamanan dan Ketertiban Rutan;

3. Pengelolaan Rutan dan Urusan Tata Usaha Rutan.

Terkait situasi permasalahan yang di temukan dan terdapatnya Organisasi dan Tata Kerja Rumah Tahanan Negara di dalam sub bagian pelayanan tahanan maka perlu dilaksanakan suatu kegiatan pelatihan yang mampu mengatasi ketidakmampuan dalam membaca dan menulis yang dialami oleh tahanan maupun narapidana yang berada di Rutan Kelas IIB Pemalang.

\section{Metode Penelitian}

Penelitian ini dilakukan dengan menggunakan pendekatan penelitian kualitatif karena di dalam penelitian ini merupakan sebuah riset yang bersifat deskriptif yang menjelaskan mengenai suatu gejala atau fenomena dengan prosedur untuk mengeksplorasi dan memahami makna yang oleh sejumlah individu atau sekelompok orang dianggap berasal dari masalah sosial atau kemanusiaan.

Jenis penelitian yang digunakan dalam penelitian ini adalah deskriptif. Menurut (Zulkhairi, 2018) penelitian deskriptif kualitatif ditujukan untuk mendeskripsikan dan menggambarkan fenomena-fenomena yang ada, baik bersifat alamiah maupun rekayasa manusia, yang lebih memperhatikan mengenai karakteristik, kualitas, keterkaitan antar kegiatan. Objek penelitian kualitatif sering disebut sebagai metode naturalistik, karena kondisi pada objek dalam penelitian tersebut apa adanya tanpa dimanipulasi.

Sumber data yang diperlukan dalam penelitian ini terdiri dari dua data, antara lain:

1. Data Primer Data primer merupakan data penelitian yang didapatkan secara langsung dari narasumber (tanpa perantara) kepada pihak yang dianggap mengetahui atau menguasai permasalahan yang akan dibahas. 
2. Data sekunder adalah data yang diperoleh dari informasi berupa publikasi yang diarsip oleh Unit Pelaksana Teknis. Data sekunder dalam penelitian ini berupa dokumen atau arsip berkas Tahanan/ Warga Binaan Pemasyarakatan

\section{Hasil dan Pembahasan}

\section{A. Tinjauan Umum Terhadap Obyek Studi}

1) Gambaran umum Rutan Klas IIB Pemalang

Table 2 Gambaran umum Rutan Klas IIB Pemalang

\begin{tabular}{lll}
\hline No & Profil UPT & \multicolumn{1}{c}{ Uraian } \\
\hline \multirow{3}{*}{ Sejarah berdiri? } & Rutan Pemalang Merupakan bangunan peninggalan \\
& Pemerintah Hindia Belanda dan didirikan tahun 1925 \\
& Kondisi bangunan Rutan Pemalang terdiri dari : \\
& -21 Kamar sel hunian yang terbagi menjadi tiga \\
& blok. \\
& -1 Mushola untuk kegiatan keagamaan. \\
& -2 Ruang ketrampilan. \\
& -1 Ruang dapur \\
& -1 Ruang kunjungan \\
& & -4 Toilet petugas \\
& & -3 Lubang sumur \\
& -6 Ruangan kantor \\
& -2 Ruangan arsip \\
& -2 Pos pantau blok hunian \\
& -4 Pos pantau atas \\
\hline
\end{tabular}

\begin{tabular}{lll}
\hline & Lokasi? & Lokasi Rutan Pemalang terletak di J1. Muchtar no. 3 \\
& Pemalang. \\
\hline 4 & Kegiatan Pembinaan & - Pembinaan Kemandirian \\
kemandirian dan & 1. Pertukangan / kerajinan kayu \\
kepribadian? & 2. Keterampilan Menjahit \\
& - Pembinaan Kepribadian \\
& 1. Pembinaan jasmani \\
& a) Senam Kesegaran Jasmani \\
& b) Olahraga Kelompok (tenis meja/sepak \\
& c) takraw) Dinamika kelompok / outbond \\
& d) Rekreasi dalam : Menonton TV
\end{tabular}

2. Pembinaan Rohani

a) Sholat berjamaah bagi WBP muslim

b) Baca Tulis Al Qur'an

c) Perpustakaan : buku-buku rohani

5 Kerjasama dengan instansi terkait?
- Dengan Polres Pemalang sbb :

1. Patroli sambang pihak Polres Pemalang 


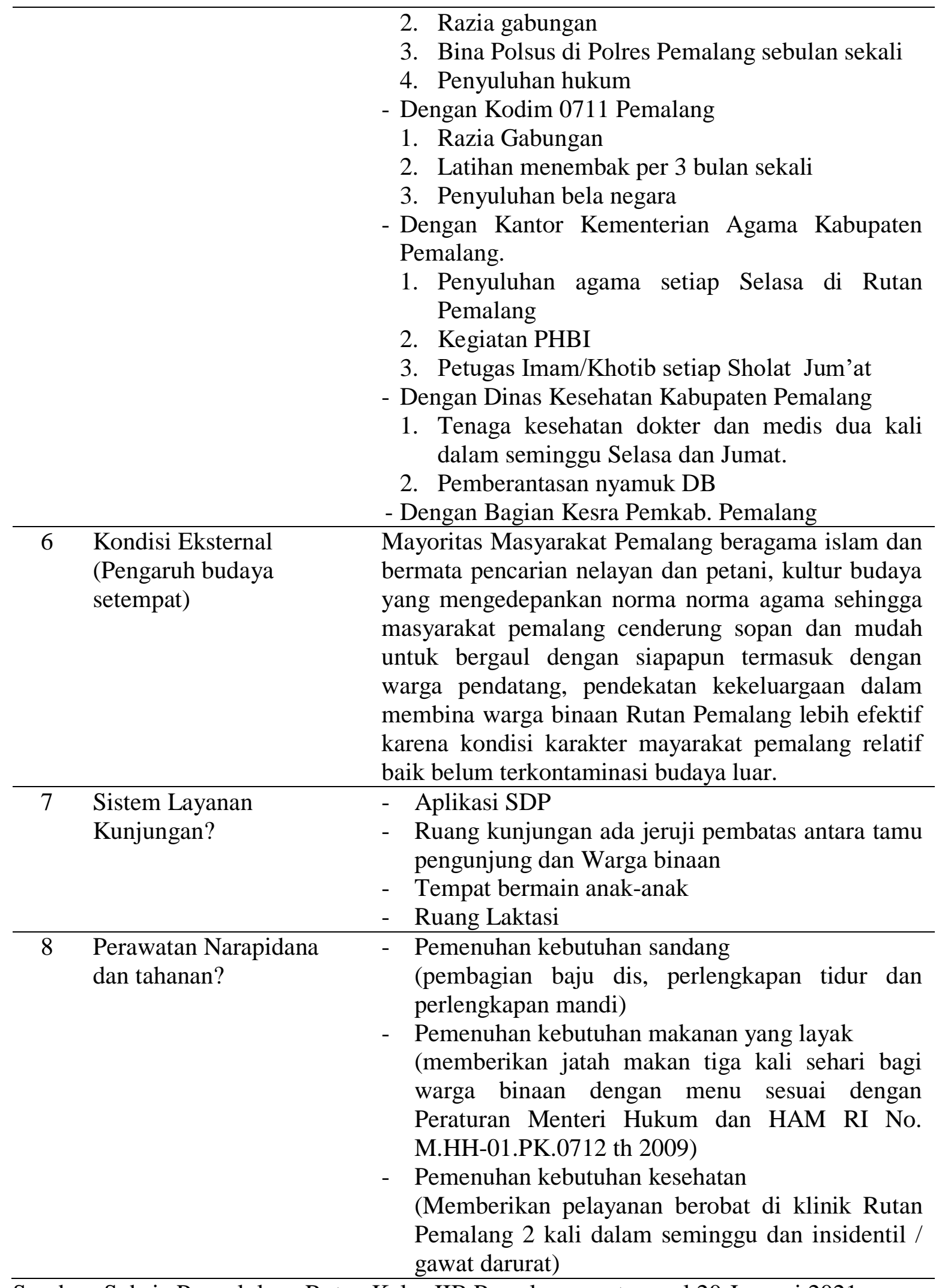

Sumber: Subsie Pengelolaan Rutan Kelas IIB Pemalang per tanggal 20 Januari 2021 


\section{2) Struktur Organisasi dan Tata Kerja}

Adapun susunan struktur organisasi dan tata kerja pegawai pada Rutan Kelas IIB Pemalang sebagai berikut:

Table 3

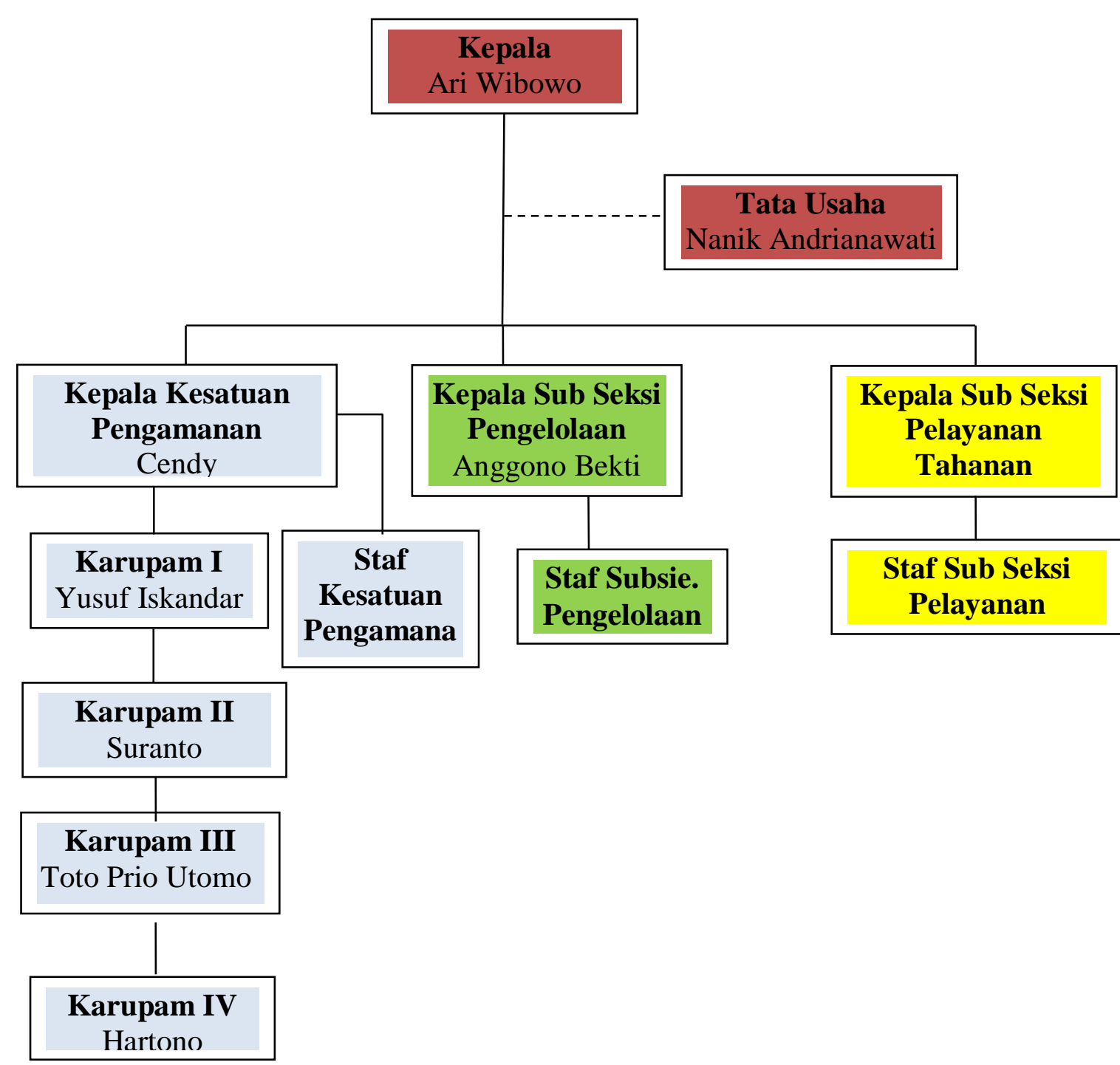

Sumber: Subsie Pengelolaan Rutan Kelas IIB Pemalang per tanggal 20 Januari 2021

Organisasi Rutan Kelas IIB Pemalang yang sesuai dengan Keputusan Menteri Kehakiman RI No.M.04.PR.07.03 Tahun 1985 terdiri dari:

\section{Kepala Rumah Tahanan Negara}

\section{Tugas Pokok Jabatan}

Mengkoordinasikan, memimpin dan mengawasi proses penerimaan, penempatan, perawatan, keamanan dan tata tertib tahanan serta bidang fasilitas Rumah Tahanan Negara sesuai dengan peraturan perundang-undangan yang berlaku untuk kepentingan penyidikan, penuntutan dan pemeriksaan di sidang pengadilan Uraian Tugas 
a) Mengkoordinasikan penyusunan rencana kerja umum Rumah Tahanan Negara dengan memadukan rencana kerja unit-unit kerja bawahan untuk menetapkan rencana kerja dan program kerja Rumah Tahanan Negara.

b) Memeriksa tahanan baru dengan cara meneliti surat penahanan dan register tahanan untuk menetapkan penempatan tahanan.

c) Mengecek hasil penggeledahan barang dan badan tahanan untuk menetapkan tindak lanjut atas hasil penggeledahan.

d) Mengatur penyelengaraan penyuluhan jasmani tahanan mendapatkan fasilitas yang tersedia juga untuk menjaga kesegaran jasmani tahanan.

e) Mengatur dan mengawasi pertemuan penasehat hukum dengan tahanan yang dibelanya dalam rangka penggunaan hak-hak tahanan untuk mendapatkan bantuan hukum secara tertib.

f) Mengatur dan mengawasi kunjungan ke Rumah Tahanan Negara dengan menetapkan waktu dan tempat tahanan.

g) Membina dan meningkatkan bakat dan keterampilan tahanan dengan meletakkan jenis dan macam kegiatan untuk menyalurkan bakat, minat dan keterampilan tahanan.

\section{Tanggung jawab}

a) Keamanan umum tata tertib Rumah Tahanan Negara.

b) Perawatan kesejahteraan tahanan dan terpidana penjara tertentu.

c) Pengawasan dan pengendalian bantuan hukum dan penyuluhan tahanan.

d) Kelancaran pelaksanaan bimbingan kegiatan tahanan.

e) Pengeluaran atau pembebasan tahanan dari Rumah Tahanan Negara.

f) Pelaporan atas segala kegiatan perawatan tahanan dan peristiwa yang terjadi dalam Rumah Tahanan Negara.

g) Administrasi keuangan, perlengkapan dan pengelolaan Rumah Tahanan Negara.

h) Pembinaan pegawai Rumah Tahanan Negara.

\section{Kepala Kesatuan Pengamanan Rumah Tahanan Negara Kelas IIB Pemalang Tugas Pokok Jabatan}

Mengkoordinasikan tugas pengamanan dan ketertiban dengan melakukan pengaturan jadwal penjagaan, penggunan peralatan keamanan dan pembagian tugas jaga agar tercipta suasana aman dan tertib dalam lingkungan Rumah Tahanan Negara.

\section{Uraian tugas}

a) Mengawasi pelaksanaan penjagaan, pengawalan dan pengawasan terhadap tahanan.

b) Mengawasi pelaksanaan penerimaan, pemempatan dan pengawasan tahanan.

c) Membantu keamanan dan tata tertib tahanan pada tingkat pemeriksaan.

d) Mengontrol sarana dan prasarana keamanan dan ketertiban Rumah Tahanan Negara.

e) Melakukan pembinan pegawai untuk menegakkan disiplin dalam rangka tata tertib dan disiplin untuk menjaga keamanan Rumah Tahanan Negara.

f) Melaksanakan penggeledahan kamar tahanan di rumah Tahanan Negara.

\section{Tanggung jawab}

a) Pembinaan pegawai bawahan.

b) Hasil pelaksanaan tugas sesuai dengan rencana kerja.

c) Disiplin pegawai. 
d) Pemeliharaan dan pengelolaan peralatan sarana dan prasarana kerja keamanan dan tata tertib.

e) Keamanan dan pengamanan Rumah Tahanan Negara dan penghuni.

f) Tata tertib tahanan dan Rumah Tahanan Negara.

g) Jadwal tugas regu jaga.

h) Penyiapan berita acara yang berkaitan dengan keamanan dan ketertiban

\section{Kepala Sub Seksi Pelayanan Tahanan Rutan Kelas IIB Pemalang} Tugas Pokok Jabatan

Mengkoordinasikan administrasi dan perawatan, mempersiapkan bantuan hukum dan penyuluhan serta pemberian bimbingan kegiatan bagi tahanan sesuai dengan perundang-undangan yang berlaku.

\section{Uraian tugas}

a) Menyusun rencana kerja.

b) Melakukan administrasi dan perawatan tahanan.

c) Mempersiapan pemberian bantuan hukum dan penyuluhan bagi para tahanan.

d) Memberikan bimbingan kegiatan kerja bagi para tahanan.

e) Melakukan koordinasi pelaksanaan tugas Departemen Hukum dengan Pemerintahan Daerah dan instansi terkait serta Organisasi Kemasyarakatan.

f) Mengkoordinasikan ketatausahaan dalam lingkungan Sub Seksi Pelayanan Tahanan.

\section{Kepala Sub Seksi Pengelolaan Rutan Kelas IIB Pemalang Tugas Pokok Jabatan}

Melaksanakan pengurusan administrasi kepegawaian, perlengkapan dan rumah tangga sesuai dengan ketentuan dan peraturan yang berlaku dalam rangka kelancaran tugas pengelolaan Rumah Tahanan Negara.

\section{Uraian tugas}

a) Mengerjakan pengetikan dan pengiriman surat keluar untuk memperlancar penyiapan informasi.

b) Meneliti konsep pertanggungjawaban penggunaan pengiriman surat dinas, teleks dan telegram sesuai dengan kuitansi atau resi bukti pengiriman.

c) Mengklasifikasikan arsip dan dokumentasi di lingkungan Ka.subsiePengelolaan.

d) Menyelenggarakan urusan kearsipan dan dokumentasi dengan mengatur kegiatan penyediaan, pelayanan pinjaman, penyimpanan dan pemeliharaan arsip surat dan dokumen kantor.

e) Meneliti dan mengoreksi konsep surat yang berkaitan dengan tugas kerumahtanggaan yang diajukan oleh bawahan.

f) Menyelenggarakan pemeliharaan kendaraan dinas agar selalu dalam keadaan siap untuk digunakan.

g) Mengatur penggunaan kendaraan dan angkutan dinas untuk menunjang kelancaran tugas.

\section{Tanggung jawab}

a) Kebenaran rencana kerja Sub.siePengelolaan.

b) Kebenaran usul, saran dan pendapat kepada atasan sesuai bidang tugas.

c) Pembinaan pegawai bawahan. 
d) Hasil pelaksanaan tugas sesuai dengan rencana kerja dan ketentuan peraturan yang berlaku.

e) Disiplin pegawai.

f) Kebenaran data laporan keuangan, kepegawaian, perlengkapan Rumah Tahanan Negara.

\section{3) Data Subtantif Pegawai Dan Penghuni}

\section{a) Keadaan Pegawai}

Tabel. 4

Data Pegawai berdasarkan tingkat Pendidikan dan jenis kelamin

\begin{tabular}{|c|c|c|c|c|c|c|c|}
\hline \multirow[t]{3}{*}{ No } & \multirow[t]{3}{*}{ Unit kerja } & \multicolumn{5}{|c|}{ Tingkat Pendidikan, Jenis Kelamin } & \multirow[t]{3}{*}{ Jumlah } \\
\hline & & S2 & S1 & DIII & \multicolumn{2}{|c|}{ SLTA } & \\
\hline & & $\begin{array}{ll}\text { LK } & \text { PR }\end{array}$ & $\begin{array}{ll}\text { LK } & \text { PR }\end{array}$ & $\begin{array}{ll}\text { LK } & \text { PR }\end{array}$ & LK & PR & \\
\hline 1. & $\begin{array}{l}\text { Kepala } \\
\text { Rutan }\end{array}$ & & 1 & & & & 1 \\
\hline 2. & Ka. KPR & & 1 & & & & 1 \\
\hline 3. & $\begin{array}{c}\text { Kasubsi. } \\
\text { Pengelolaan }\end{array}$ & & 1 & & & & 1 \\
\hline 4. & $\begin{array}{c}\text { Kasubsi } \\
\text { Pelayanan } \\
\text { Tahanan }\end{array}$ & & 1 & & & & 1 \\
\hline 5. & $\begin{array}{c}\text { Staf } \\
\text { pengelolaan }\end{array}$ & & & & 3 & 2 & 5 \\
\hline 6. & $\begin{array}{c}\text { Staf } \\
\text { pelayanan } \\
\text { tahanan }\end{array}$ & & 1 & & 3 & 3 & 7 \\
\hline 7. & $\begin{array}{c}\text { Petugas } \\
\text { pengamanan }\end{array}$ & & 2 & & 23 & & 25 \\
\hline & Jumlah & & 7 & & 29 & 5 & 41 \\
\hline
\end{tabular}

Sumber: Subsie Pengelolaan Rutan Kelas IIB Pemalang per tanggal 20 Januari 2021

Berdasarkan tabel diatas mayoritas pegawai Rutan kelas II B Pemalang adalah lulusan SMA yaitu sebayak 34 orang atau $83 \%$ dan S1 berjumlah 7 orang atau $17 \%$ dari keselurahan pegawai.

Tabel. 5

Daftar Pegawai berdasarkan kepangkatan di Rutan Kelas IIB Pemalang

\begin{tabular}{|c|c|c|c|c|}
\hline \multirow[t]{2}{*}{$\mathrm{NO}$} & \multirow[t]{2}{*}{ Golongan } & \multicolumn{2}{|c|}{ Jenis Kelamin } & \multirow[t]{2}{*}{ Jumlah } \\
\hline & & Pria & Wanita & \\
\hline 1 & IV/A & & & \\
\hline 2 & III/D & 2 & & 2 \\
\hline 3 & $\mathrm{III} / \mathrm{C}$ & 1 & & 1 \\
\hline 4 & III/B & 10 & 3 & 13 \\
\hline 4 & III/A & 5 & & 5 \\
\hline
\end{tabular}




\begin{tabular}{ccccc}
\hline 5 & II/D & 2 & 2 \\
\hline 6 & II/C & 1 & & 1 \\
\hline 7 & II/B & 6 & 2 & 6 \\
\hline 8 & II/A & 9 & 5 & 41 \\
\hline & JUMLAH & 36 & 11
\end{tabular}

Sumber : Subsie Pengelolaan Rutan Kelas IIB Pemalang per tanggal 20 Januari 2021

Berdasar tabel diatas pegawai dengan golongan II/A berjumlah 11 orang atau 27 $\%$ hingga golongan III/D berjumlah 13 orang atau $32 \%$ dari total keseluruhan pegawainya, pangkat pegawai paling dominan adalah II/A dan III/B sementara pada jenjang kepangkatan lainya persebaranya cukup merata.

\section{b) Keadaan Penghuni (Tahanan/Warga Binaan Pemasyarakatan)}

Rutan Kelas II B Pemalang memiliki kapasitas sebesar 120 orang tetapi dihuni dengan 174 orang penghuni, berikut data penghuni Rutan kelas II B Pemalang

Tabel. 6

Data Penghuni Rutan kelas II B Pemalang

\begin{tabular}{|c|c|c|c|c|}
\hline \multirow[t]{2}{*}{ REG } & \multicolumn{2}{|c|}{ DEWASA } & \multicolumn{2}{|l|}{ ANAK } \\
\hline & $\mathrm{P}$ & $W$ & $\mathrm{P} \quad \mathrm{W}$ & \\
\hline A I & 2 & & & 2 \\
\hline A II & 11 & & & 11 \\
\hline A III & 33 & 1 & & 34 \\
\hline A IV & & & & \\
\hline A V & 1 & & & 1 \\
\hline Jumlah & 47 & 1 & & 48 \\
\hline Mati & & & & \\
\hline $\begin{array}{l}\text { Seumur } \\
\text { Hidup }\end{array}$ & & & & \\
\hline B I & 103 & 2 & & 105 \\
\hline B II a & 19 & 1 & & 20 \\
\hline B II b & & & & \\
\hline B III & 1 & & & 1 \\
\hline Jumlah & 123 & 3 & & 126 \\
\hline Total & 170 & 4 & & 174 \\
\hline
\end{tabular}

Sumber : Staf KPR Rutan Kelas IIB Pemalang per tanggal 20 Januari 2021

Berdasarkan data diatas Rutan Kelas IIB Pemalang memiliki total 174 penghuni dengan tahanan sebanyak 48 orang atau $28 \%$ sedangkan narapidana sebanyak 126 orang atau $72 \%$. penghuni berjenis kelamin laki-laki sebanyak 170 orang dan wanita sebanyak 4 orang dari data keseluruhan penghuni Rutan Kelas IIB Pemalang.

\section{B. Strategi pelayanan pendidikan dan pengajaran untuk memenuhi Hak dan kewajiban Tahanan}

1. Gambaran umum Pemberian Hak pelayanan pendidikan dan pengajaran 
Menurut Undang- Undang Nomor 2 Tahun 1989 tentang Sistem Pendidikan Nasional pada Bab I Pasal 1 ayat (2) disebutkan "Pendidikan Nasional adalah pendidikan yang berakar pada kebudayaan bangsa Indonesia dan yang berdasarkan Undang- Undang Dasar RI 1945”. Undang- Undang RI Nomor 20 tahun 2003 tentang Pendidikan Nasional Pasal 1 ayat (1) dikatakan bahwa pendidikan adalah usaha sadar dan terencana untuk mewujudkan suasana belajar dan proses pembelajaran agar peserta didik secara aktif mengembangkan potensi dirinya untuk memiliki kekuatan spiritual keagamaan, pengendalian diri, kepribadian kecerdasan, akhlak mulia, serta keterampilan yang diperlukan dirinya, masyarakat bangsa dan negara (Wahdaningsi, 2015). Pendidikan dan Pengajaran akan memiliki nilai tambah yang akan mengisi aktivitas mereka seharihari. Pendidikan dan pengajaran akan memudahkan mereka untuk faham akan pranata sosial yang berlaku di tengah masyarakat kita (Muhammad Zakariah, 2018).

Pelaksanaan hak warga binaan pemasyarakatan merupakan upaya pembinaan yang bersifat berkesinambungan. Upaya pembinaan tersebut menjadi indikator pelaksanaan pidana penjara untuk mencapai tujuan dari sistem pemasyarakatan (Kusuma, 2013).Sesuai peraturan pemerintah Republik Indonesia Nomor 58 tahun 1999 tentang syarat-syarat dan tata cara pelaksanaan wewenang, tugas dan tanggung jawab perawatan tahanan yang tertuang pada pasal 20 tentang Pendidikan dan Pengajaran yaitu :

(1) Bagi tahanan dapat diberikan kesempatan mengikuti pendidikan dan pengajaran.

(2) Pelaksanaan pendidikan dan pengajaran bagi tahanan sebagaimana dimaksud dalam ayat

1) dapat berupa :

a. penyuluhan hukum;

b. kesadaran berbangsa dan bernegara; dan

c. lainnya sesuai dengan program perawatan tahanan.

Tujuan merupakan standar usaha yang dapat ditentukan serta mengarahkan usaha yang akan dilalui dan merupakan titik pangkal untuk mencapai tujuan-tujuan yang lain. Di samping itu tujuan mampu membatasi ruang gerak usaha, agar kegiatan dapat terfokuskan pada apa yang akan dicapai. Dan yang terpenting adalah dapat memberi penilaian atau evaluasi pada usaha-usaha pendidikan (Zelaekha, 2015).

Dapat ditarik suatu kesimpulan, bahwa pendidikan merupakan hak-hak tiap warga negara tanpa terkecuali, sebab pendidikan harus dilaksanakan secara demokratis, berkeadilan, tidak diskriminatif dengan menjunjung tinggi hak asasi manusia, nilai-nilai kegamaan, nilai kultural, dan kemajemukan bangsa. Pendidikan yang penyelenggaraanya tidak membeda-bedakan siapapun dan dengan menjunjung nilainilai yang berlaku dalam masyarakat, maka terselenggaranya pendidikan merupakan tanggung jawab seluruh lapisan masyarakat, dan terutama oleh pemerintah. Sehingga 
diharapkan dengan campur tangan pemerintah, seluruh warga negara memperoleh hak mereka yaitu mendapatkan pendidikan yang layak tanpa terkecuali (Rahmawati, 2017).

Keberadaan sebagian kecil tahanan dan narapidana yang masih belum bisa membaca dan menulis masih terjadi di Rutan Kelas IIB Pemalang. Berdasarkan data yang diperoleh dari sub seksi pelayanan tahanan Rutan Kelas IIB Pemalang, terdapat 14 tahanan maupun narapidana yang belum bisa membaca dan menulis. Penyebabnya antara lain disebabkan karena faktor latar belakang kehidupannya terkait tingginya kemiskinan, desakan ekonomi yang menuntut bekerja keras, malas belajar secara formal karena sebagian besar materinya bersifat teori atau tidak dapat secara langsung dirasakan manfaatnya, hingga rasa malu mengakui kekurangan dirinya. (Hartono, 2010)

Hal ini membuat kurang maksimalnya proses pemberian pelayanan kepada tahanan maupun narapidana yang berada di Rutan Kelas IIB Pemalang, contoh saja pada saat warga binaan pemasyarakatan akan menggunakan layanan Self Service, beberapa warga binaan tersebut terkendala oleh ketidakmampuannya dalam membaca dan menulis sehingga mereka tidak dapat menggunakan layanan tersebut dengan maksimal dan untuk mendapatkan informasi mereka hanya bisa bertanya kepada petugas pemasyarakatan.

Terkait situasi permasalahan yang di temukan dan terdapatnya Organisasi dan Tata Kerja Rumah Tahanan Negara di dalam sub bagian pelayanan tahanan maka perlu dilaksanakan suatu kegiatan pelatihan yang mampu mengatasi ketidakmampuan dalam membaca dan menulis yang dialami oleh tahanan maupun narapidana yang berada di Rutan Kelas IIB Pemalang sehingga dapat membaca dan menulis pada tingkat dasar yaitu dengan :

1. Pemberian kegiatan pelatihan membaca dan menulis untuk tahanan / narapidana yang belum bisa membaca dan menulis melalui pembentukan Kelompok Belajar yang kami sebut "KEJAR".

2. Pendampingan terhadap penggunaan fitur layanan berupa Self Service untuk dapat membantu warga binaan pemasyarakatan yang tidak bisa membaca juga untuk memberikan pemahaman akan kegunaan layanan self service.

3. Pelaksanaan kegiatan perpustakaan keliling yang dilaksanakan oleh Rutan Kelas IIB Pemalang.

Pemberian kegiatan pelatihan berupa giat baca tulis untuk tahanan / narapidana yang belum bisa membaca dan menulis diharapkan dapat mempermudah proses komunikasi, dan mewujudkan tujuan bangsa Indonesia ke-3 pada alinea ke-IV UUD 1945 yaitu "Mencerdaskan kehidupan bangsa" yang dilakukan pemerintah khususnya di lingkungan Rutan Kelas IIB Pemalang.

Program KEJAR adalah kegiatan pemberian hak Tahanan berupa pelatihan membaca dan menulis bagi kelompok masyarakat khususnya tahanan dan narapidana di Rutan Kelas IIB Pemalang dengan tujuan bisa membaca dan menulis. Pembimbing setiap kelompok ialah siapa saja yang berpendidikan minimal wajib belajar 9 tahun. Jumlah peserta dan waktu pelaksanaan setiap kelompok belajar bersifat fleksibel. 
Warga belajar adalah sebutan bagi warga binaan pemasyarakatan yang mengikuti kegiatan pelatihan membaca dan menulis dalam kelompok belajar di Rutan Kelas IIB Pemalang.

\section{Uraian Kegiatan}

1) Berkonsultasi dengan pembimbing, pejabat dan para pegawai yang terkait dalam pelaksanaan kegiatan:

a. Melakukan konsultasi dengan pembimbing dan pejabat terkait dalam memberikan hak tahanan dengan melaksanakan pelatihan giat baca tulis terhadap tahanan dan narapidana yang belum bisa membaca dan menulis guna memenuhi perawatan tahanan di dalam Rutan.

b. Menyampaikan ide tentang solusi dari permasalahan kepada pejabat terkait.

c. Mencatat masukan dan arahan dari pejabat terkait.

2) Pendataan warga belajar dan perencanaan kegiatan pelatihan :

a. Melakukan pendataan terhadap tahanan dan narapidana yang belum bisa membaca dan menulis

b. Melakukan perencanaan kegiatan pelatihan yang akan dilakukan.

c. Menyiapkan pembimbing kelompok belajar

\section{3) Pra pelaksanaan}

a. Menyiapkan peralatan yang digunakan untuk kegiatan pelatihan giat baca tulis

b. Menentukan jadwal untuk kegiatan

c. Menyiapkan materi yang akan disampaikan

4) Pelaksanaan dan pemantauan :

a. Melaksanakan kegiatan pembelajaran sesuai dengan jadwal dan materi yang sudah direncanakan.

b. Melaksanakan pembelajaran kepada warga belajar dengan tetap memperhatikan aturan

c. Melakukan pemantauan terkait pelaksanaan kegiatan dengan memperhatikan peningkatan kemampuan pada warga belajar

\section{5) Evaluasi selama pelaksanaan :}

Melakukan tes membaca dan menulis kepada warga belajar baik secara individu maupun kelompok.

\section{A. Pelaksanaan}

1. Berkonsultasi kepada Kepala Sub Seksie Pelayanan Tahanan

Melaksanakan konsultasi dan koordinasi terkait kegiatan kepada pejabat terkait hak tahanan yang belum terlaksana di dalam Rutan klas IIB Pemalang. Dalam pemberian perawatan tahanan dengan melaksanakan kegiatan pelatihan membaca dan menulis terhadap tahanan dan narapidana yang belum bisa membaca dan menulis di Rutan Kelas IIB Pemalang. Karena dengan adanya konsultasi dan koordinasi ini di Rumah Tahanan Negara Kelas IIB Pemalang dengan baik dalam mencapai target yang ingin dicapai

2. Pendataan warga belajar dan sosialisasi 
Melaksanakan kegiatan pendataan terhadap tahanan dan narapidana yang belum bisa membaca dan menulis di Rutan Kelas IIB Pemalang. Setelah mendapatkan data, kami melaksanakan sosialisasi yaitu memberikan arahan mengenai kegiatan pelatihan membaca dan menulis melalui program "KEJAR" yang merupakan singkatan dari kelompok belajar terhadap Warga Binaan Pemasyarakatan yang belum bisa membaca dan juga menulis di Rutan Kelas IIB Pemalang.

Berikut hasil pendataan warga binaan pemasyarakatan yang mengikuti kegiatan pelatihan membaca dan menulis di Rutan Kelas IIB Pemalang :

Tabel. 7

\begin{tabular}{llcccc}
\hline NO & NAMA WBP & BLOK & MEMBACA & MENULIS & KETERANGAN \\
\hline 1 & Karnoto Bin Raswan & A & Tidak & Tidak & Tidak Sekolah \\
\hline 2 & Abdul Rozak Bin Subahan & A & Tidak & Tidak & Tidak Sekolah \\
\hline 3 & Dairin Bin Kasadi & A & Tidak & Tidak & Tidak Sekolah \\
\hline 4 & Salil Bin Kaliri & A & Tidak & Tidak & Tidak Sekolah \\
\hline 5 & Aris Bianto Bin Johari & A & Tidak & Tidak & Putus SD Kelas 1 \\
\hline 6 & Pendi Ajis Bin Sudarno & A & Tidak & Tidak & Putus SD Kelas 1 \\
\hline 7 & Mardi Bin Muhari Caslan & A & Tidak & Tidak & Putus SD Kelas 2 \\
\hline 8 & Samari Bin Raswali & B & Tidak & Tidak & Tidak Sekolah \\
\hline 9 & Wanna Bin Karal & B & Tidak & Tidak & Tidak Sekolah \\
\hline 10 & Kadis Bin Kasan & B & Tidak & Tidak & Tidak Sekolah \\
\hline 11 & Sahmad Bin Sahir & B & Tidak & Tidak & Tidak Sekolah \\
\hline 12 & Wasmo Bin Tari & B & Tidak & Tidak & Tidak Sekolah \\
\hline 13 & Sulam Bin Sunarto & B & Tidak & Tidak & Tidak Sekolah \\
\hline 14 & Sutarjo Bin Sardi & B & Tidak & Tidak & Putus SD Kelas 1
\end{tabular}

Sumber : Data Sub Seksi Pelayanan Tahanan Rutan Kelas IIB Pemalang

3. Pra pelaksanaan

a) Menyiapkan peralatan yang digunakan untuk kegiatan pelatihan membaca dan menulis

b) Menyiapkan tempat kegiatan pelatihan membaca dan menulis

c) Menentukan jadwal untuk kegiatan 
Praktik kegiatan pelatihan kelompok belajar dengan jadwal dalam pelaksanaan pelatihan membaca dan menulis di Rumah Tahanan Negara Kelas IIB Pemalang adalah sebagai berikut

Tabel. 8

\begin{tabular}{llll} 
No & Hari/tanggal & Waktu & \multicolumn{1}{c}{ Materi } \\
\hline 1. & Senin- Sabtu 11-16Pukul. 08.00- Observasi dan pendataan warga \\
Januari 2021 & 15.00 WIB. & $\begin{array}{l}\text { belajar } \\
\text {-Persiapan alat }\end{array}$
\end{tabular}

Data pribadi Warga Belajar dan mengukur kemampuan awal warga belajar.

\section{Senin- Sabtu 18- Pukul. 08.30- Pengenalan huruf vocal dan} 23 Januari 2021 10.00 WIB. konsonan
Media :
White board, spidol, buku, pensil, poster huruf dan puzzle huruf

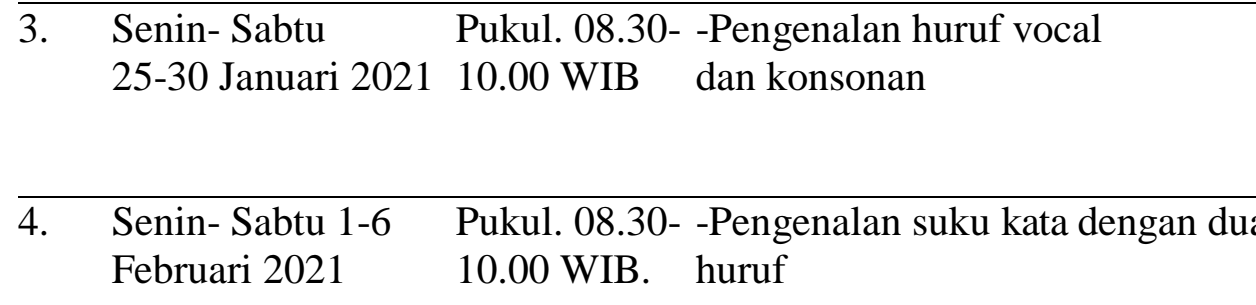

Media :

White board, spidol, buku, pensil, poster huruf dan puzzle huruf

Februari $2021 \quad 10.00$ WIB. huruf

White board, spidol, buku, pensil, poster huruf dan puzzle huruf

5. $\quad$ Senin- Sabtu 8-13 Pukul. 08.30- Penyegaran terhadap huruf Media :

Februari $2021 \quad 10.00$ WIB. konsonan dan huruf vocal disertai White board, spidol, menyusun suku buku, pensil, poster kata dengan dua huruf huruf dan puzzle huruf

6. Senin- Sabtu 15-20 Pukul. 08.30- -Pelatihan menulis huruf pada Februari $2021 \quad 10.00$ WIB. buku halus Media : Buku halus dan pensil pada masing-masing warga belajar

7. Senin- Sabtu 22-27 Pukul. 08.30- Pelatihan menulis huruf pada Praktek langsung baik Februari $2021 \quad 10.00$ WIB. buku halus dan dapat menggabungkannya menjadi kelompok sebuah kata

8. Senin- Selasa 1-2 Pukul. 08.30- Tes membaca Media : Soal tes Maret 2021 10.00 WIB. -Tes Menulis

d) Menyiapkan materi yang akan disampaikan

4. Pemantauan 
a) Melaksanakan kegiatan pembelajaran sesuai dengan jadwal yaitu setiap hari senin- $\quad$ sabtu dimulai pada pukul 08.30 - 10.00 WIB dengan materi yang sudah dijadwalkan

b) Melaksanakan pembelajaran kepada warga belajar dengan tetap memperhatikan aturan

c) Melakukan pemantauan terkait pelaksanaan kegiatan dengan memperhatikan peningkatan kemampuan pada warga belajar

5. Evaluasi selama pelaksanaan

Dalam melaksanakan kegiatan evaluasi selama pelaksanaan ini berupa tes membaca dan menulis kepada warga belajar secara individu maupun kelompok.

\section{B. Capaian Kegiatan}

Capaian kegiatan merupakan hasil dari realisasi kegiatan penelitian di Rutan Kelas IIB Pemalang. Dalam melaksanakan kegiatan yang dibuat dalam sebuah karya tulis dan kepada pembimbing, pejabat dan para pegawai Rutan Kelas IIB Pemalang berperan penting dan dominan dalam mendukung keberhasilan dalam melaksanakan semua kegiatan di Rutan Kelas IIB Pemalang. Dengan kerjasama yang baik dengan pembimbing maupun pejabat dan pegawai yang terkait sehingga semua kegiatan dapat berjalan dengan lancar tanpa ada kendala yang berarti.

Adapun capaian kegiatan pelatihan membaca dan menulis pada kuliah kerja nyata yang dilakukan di Rutan Kelas IIB Pemalang adalah sebagai berikut :

1. Membagi menjadi dua kelas berdasarkan pemantauan peningkatan kemampuan pada warga belajar, yaitu :

- Kelas A

Kelas untuk warga belajar yang belum memahami huruf sama sekali. Kelas A terdiri atas 7 (tujuh) warga belajar.

- Kelas B

Kelas untuk warga belajar yang sudah cukup pandai dalam memahami huruf.

Kelas B terdiri atas 7 (tujuh) warga belajar.

2. Pembagian ini bertujuan untuk memudahkan pemberian materi sesuai dengan kemampuan warga belajar diantaranya dalam pengenalan huruf abjad A-Z sehingga diharapkan dapat mengenal dan dapat menyebutkan satu persatu huruf abjad baik secara individu maupun kelompok .

3. Mempraktikkan pemahaman membaca huruf dengan latihan menulis abjad A-Z dengan media buku halus sehingga dapat mengenali bentuk dan perbedaan masingmasing huruf abjad dengan baik.

4. Membedakan huruf vokal dan konsonan sehingga dapat menyambung dua huruf dan diharapkan dapat membaca dan menulis minimal 5 suku kata sederhana.

5. Diharapkan program pelatihan membaca dan menulis dapat berlanjut dan terus dilaksanakan sebagai bentuk kegiatan pelayanan di Rutan Kelas IIB Pemalang. 


\section{Kesimpulan}

Dapat disimpulkan bahwa Kegiatan di Rutan Kelas IIB Pemalang telah terlaksana dengan baik, serta sesuai dengan jadwal pelaksanaan yang telah ditentukan sebelumnya. Pelaksanaan penelitian meliputi berbagai rangkaian kegiatan yang dapat dilihat yakni pada bidang pemberian pelayanan pendidikan dan pengajaran dalam memberikan hak tahanan, berbagai kegiatan yang dilakukan meliputi pelatihan berupa membaca dan menulis, pengenalan huruf, pengejaan huruf, pendampingan terhadap penggunaan fitur layanan berupa Self Service untuk dapat membantu WBP yang tidak membaca juga untuk memberikan pemahaman akan kegunaan layanan self service serta kegiatan perpustakaan keliling yang dilaksanakan oleh Rutan Kelas IIB Pemalang.

Kegiatan ini memberikan Hak dan Kewajiban Tahanan di dalam Rutan dengan pelatihan membaca dan menulis tingkat dasar kepada tahanan/narapidana yang belum bisa membaca agar lebih cepat memahami. Kegiatan tersebut dapat terlaksana dengan baik karena pihak yang saling berkaitan sangat mendukung. WBP semangat mengikuti pembelajaran sehingga diharapkan tercapainya tujuan Kuliah Kerja Nyata dalam mewujudkan tujuan bangsa Indonesia ke- 3 yang terdapat pada alinea ke-IV UUD 1945 yaitu "Mencerdaskan kehidupan bangsa" yang dilakukan pemerintah khususnya di lingkungan Rutan Kelas IIB Pemalang.

Tahanan/narapidana yang belum bisa membaca dapat mengikuti kegiatan dan dapat menerima manfaat dari adanya kegiatan tersebut.

Untuk itu kami sangat mengharapkan pihak Unit Pelaksana Teknis maupun masyarakat peduli akan pentingnya pendidikan dan dapat merangkul siapapun yang memiliki keterbatasan dengan metode yang sesuai dengan kebutuhan mereka (secara fungsional) maka dari itu untuk mewujudkan hak dan kewajiban bagi Tahanan dalam pelayanan berupa pendidikan dan pengajaran melalui pemberantasan buta aksara yang sekaligus dapat mewujudkan tujuan bangsa indonesia yang cerdas.

Bagi Unit Pelaksana Teknis atau pihak terkait disarankan untuk dapat dilaksanakan pemantauan data tahanan/narapidana yang masih belum bisa membaca dan menulis dengan melalukan pendataan, sehingga terpenuhinya Hak dan Kewajiban bagi tahanan/narapidana yang belum bisa membaca dan menulis terkadang malu mengakui keterbatasan dirinya dapat mengikuti kegiatan pelatihan tersebut sebagai wujud usaha mencerdaskan kehidupan bangsa. 
Tenisia Agustin

\section{Bibliography}

Christian, R. (2020). Implementasi pemenuhan hak-hak tahanan di rutan. Justitia : Jurnal Ilmu Hukum dan Humaniora, 7(2), 246.

Ermis Suryana, B. A. (2017). Pemenuhan Hak-Hak Pendidikan Keagamaan Islam Anak Binaan di Lembaga Pemasyarakatan Pakjo Palembang. Tadrib: Jurnal Pendidikan Agama Islam , 167.

Hartono, Y. D. (2010). Praktik Keaksaraan Fungsional. surabaya: Academia education.

Kusuma, F. P. (2013). Implikasi Hak-Hak Narapidana dalam Upaya Pembinaan Narapidana dalam Sistem Pemasyarakatan. Recidive : Jurnal Hukum Pidana dan penanggulangan Kejahatan, 103.

Muhammad Zakariah, h. k. (2018). Pola Pengajaran dan Pendidikan Warga Binaan Rumah Tahanan (RUTAN) Kelas II B Kabupaten Kolaka dengan adopsi Kurikulum Pondok Pesantren Al-Mawaddah Warrahmah. Jurnal Teknologi Pendidikan Madrasah, 16.

Raharjo, A. H. (2014). Pemenuhan Hak Narapidana Anak Untuk Mendapatkan Pendidikan di Lembaga Pemasyarakatan. Skripsi. Universitas Hasanuddin Makassar.

Rahmawati, A. P. (2017). Implementasi Pendidikan dan Pengajaran Bagi Warga. Universitas Muhammadiyah Malang, 48.

Sulhin, I. (2010). Filsafat (Sistem) Pemasyarakatanfilsafat (Sistem) Pemasyarakatan. Jurnal Kriminologi Indonesia, 144.

Wahdaningsi. (2015). Implementasi Hak Narapidana Untuk Mendapatkan Pendidikan dan. Hasil Penelitian Mahasiswa Universitas Hasanuddin Makassar.

Wulandari, S. (2015). Fungsi Sistem Pemasyarakatan dalam Merehabilitasi dan Mereintegrasi Sosial Warga Binaan Pemasyarakatan. Serat Acitya : Jurnal Ilmiah, 4(2), 87.

Zelaekha, U. (2015). Implementasi pembelajaran pendidikan agama islam (pai) bagi narapidana anak di lembaga pemasyarakatan anak kutoarjo jawa tengah. Skripsi.universitas islam negeri walisongo semarang, 31.

Zulkhairi, A. S. (2018). Studi Deskriptif Kualitatif: Persepsi Remaja Terhadap Perilaku Menyimpang. Jurnal Ners Indonesia, 148. 